\title{
PEMANFAATAN APLIKASI GIS UNTUK PEMETAAN POTENSI PERTANIAN DI KABUPATEN MINAHASA UTARA
}

\author{
Aneke Wowor \\ Program Studi Teknik Elektro, Fakultas Teknik, Universitas Sam Ratulangi, \\ Jl. Kampus UNSRAT Bahu, Manado, 95115, Indonesia \\ E-mail: aneke.wowor@unsrat.ac.id
}

\begin{abstract}
Abstrak
Aplikasi GIS memungkinkan pembuatan peta manual menjadi peta digital dengan menggunakan teknologi komputer yang akhirnya memberikan kemudahan-kemudahan bagi masyarakat yang ingin mengetahui letak geografis suatu wilayah. Pertanian merupakan salah satu potensi yang sangat penting bagi masyarakat Indonesia khususnya kabupaten Minahasa Utara. Karena sebagian besar masyrakatnya berprofesi sebagai petani. Setiap petani selalu mengharapkan hasil yang terbaik dari hasil pertanianya untuk memenuhi kebutuhan hidup mereka sehari-hari. Banyak daerah pertanian di kebupaten Minahasa Utara ini yang belum ditanami tanaman pertanian yang cocok dengan keadaan tanah tersebut. Sehingga banyak tanaman pertanian yang bisa menjadi produk unggulan tetapi tidak dibudidayakan. Hal ini disebabkan karena mereka hanya mengandalkan pengetahuan dari nenek moyang atau pendahulu mereka. Kurangnya pengetahuan dari para petani mengenai keadaan tanah di daerah mereka, menyebabkan mereka lebih cenderung menanam tanaman pertanian yang sudah ada sebelumnya seperti kelapa, jagung, pisang dan lain-lain.
\end{abstract}

Kata Kunci: Aplikasi GIS, Potensi Pertanian, Minahasa Utara

\section{Pendahuluan}

Sistem Informasi Geografis merupakan salah satu model sistem informasi yang banyak digunakan untuk membuat berbagai keputusan, perencanaan, dan analisis. Sistem Informasi Geografis (SIG) adalah teknologi yang berbasis grafis yang berhubungan dengan pemanfaatan wilayah yang luas. Melalui SIG banyak manfaat yang didapatkan baik dari segi pelayanan, perencanaan, pembangunan maupun pemeliharaan.

Penggunaan Sistem Informasi Geografis (SIG) meningkat tajam sejak tahun 1980-an. Peningkatan pemakaian sistem ini terjadi dikalangan pemerintah, militer, akademis atau bisnis terutama di negara-negara maju. Perkembangan teknologi digital sangat besar peranannya dalam perkembangan penggunaan SIG dalam berbagai bidang. Hal ini dikarenakan teknologi SIG banyak mendasarkan pada teknologi digital sebagai alat analisis.

Pemanfaatan SIG secara terpadu dalam sistem pengolahan citra digital adalah untuk memperbaiki hasil klasifikasi. Dengan demikian peranan teknologi SIG dapat diterapkan pada operasionalisasi penginderaan jauh satelit.
Pengembangan teknologi penginderaan jauh satelit dapat digambarkan dalam diagram sebagai berikut (Lihat Gbr. 1) :

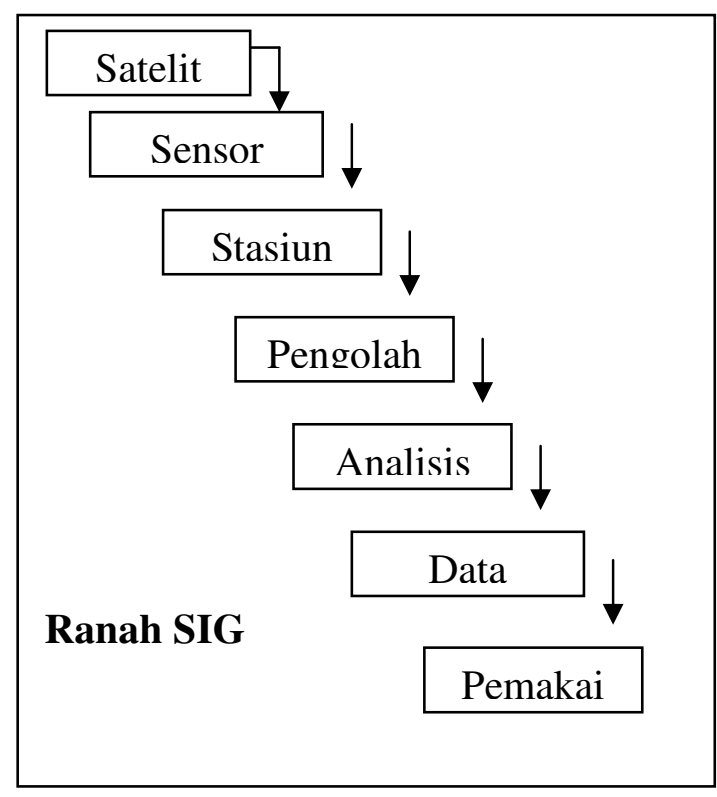

Gbr. 1 Ranah SIG 
Sedangkan SIG dapat diuraikan menjadi beberapa sub system seperti pada Gbr. 2 berikut:

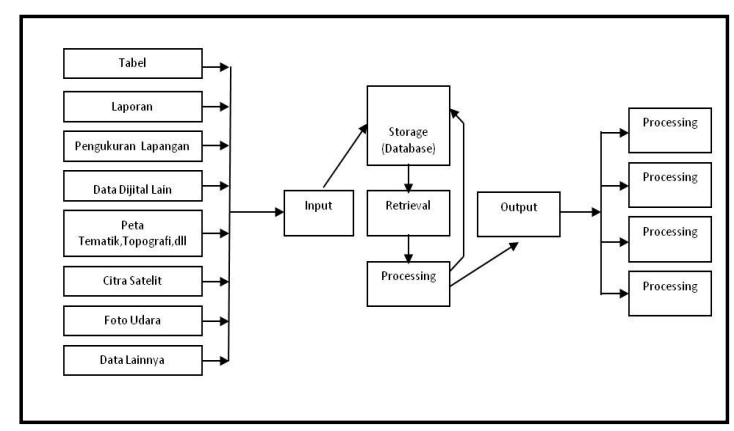

Gbr. 2 Sub Sistem SIG

\section{SIG Kecamatan Dimember Minahasa Utara}

Pembuatan aplikasi SIG untuk pengembangan potensi pertanian di Minahasa Utara, perlu dilakukan langkah-lagkah sebagai berikut (lihat Gbr. 3):

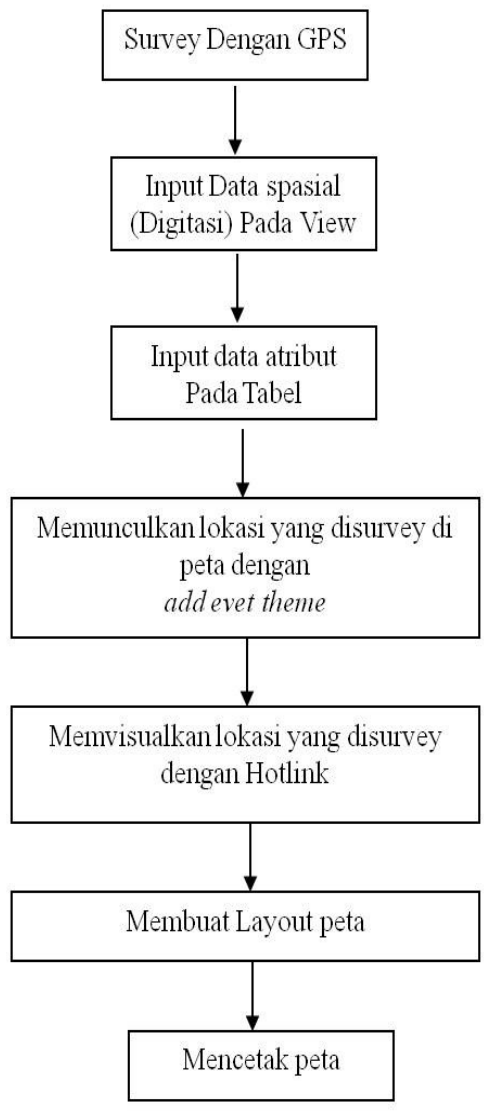

Gbr. 3 Diagram Blok Pemetaan Potensi Pengembangan Pertanian menggunakan SIG

\section{Pembahasan}

Berikut ini adalah peta berdasarkan jenis tanah yang ada di Kabupaten Minahasa Utara. (lihat Gbr. 4)

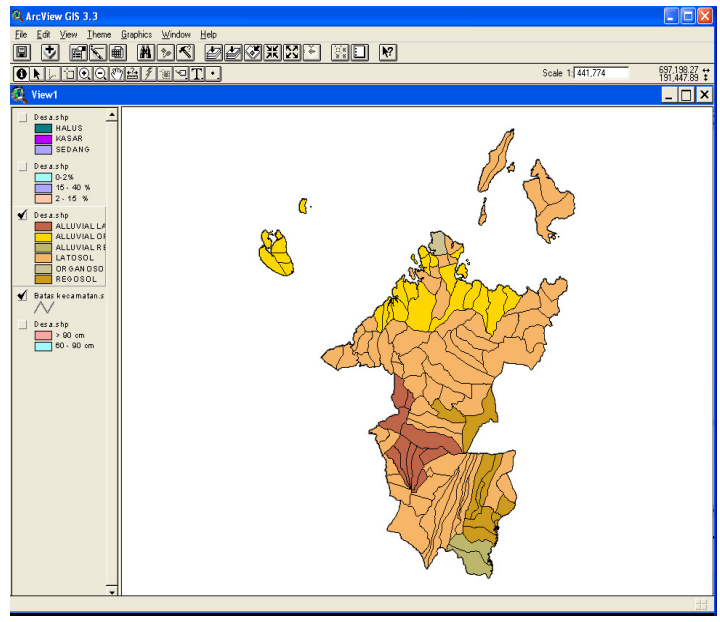

Gbr. 4 Peta Kabupaten Minahasa Utara berdasarkan Jenis Tanah

Dari peta jenis tanah di atas kita dapat melihat bahwa Kabupaten Minahasa Utara memiliki 4 jenis tanah, yaitu:

1) Latosol, yaitu jenis tanah yang paling muda, sehingga bahan induknya sering dangkal sehingga bahan induknya sering kali dangka atau tampak tanah sebagai batuan padat yang padu. Tanah ini belum mengalami perkembangan tanah, akibat pengaruh iklim yang lemah, letusan vulkan atau topografi yang terlalu miring atau bergelombang.

2) Tanah alluvial, yaitu jenis tanah yang meliputi lahan yang sering atau baru saja mengalami banjir, sehingga dapat diangggap masih muda dan belum ada diferensiasi horizon. Kandungan tanah tergantung dari jenis bahan yang di bawahnya

3) Regosol, jenis tanah ini umumnya belum jelas membentuk diferensiasi horizon.

4) Organosol atau tanah gambut atau tanah organik merupakan jenis tanah yang berasal dari bahan induk organic seperti hutan rawa atau rumput rawa, dengan ciri dan sifat: tidak terjadi diferensiasi horizon secara jelas, ketebalan lebih dari 0,5 meter, warna coklat hingga kehitaman, tekstur debu lempung, tidak berstruktur, konsistensi tidak lekat-agak lekat, kandungan organic lebih dari 30\% untuk tanah tekstur lempung dan lebih dari $20 \%$ untuk tanak testur pasir, umumnya bersifat sangat asam $(\mathrm{pH} 4.0)$, kandungan unsure hara rendah.

Berdasarkan peta jenis tanah di atas maka 
kita dapat mengetahui bahwa sebagian desa di kecamatan Wori yaitu desa Talawaan Atas, Tiwoho, Wori, Talawaan Bantik, Kima Bajo, Minaesa,dan desa Budo merupakan desa-desa yang memiliki jenis tanah Latosol. Menurut Kastapoetra (1989) tanah latosol memiliki sifatsifat : tingkat kesuburan tanah sedang, kurang akan unsure hara, sifat kimia tanah tidak baik, walaupun sifat fisiknya baik akan tetapi rentan pula terhadap erosi. Untuk jenis tanah ini penulis menyarankan agar para petani menanam tanaman seperti : mangga, rambutan, padi sawah, padi gogo, jagung, kacang tanah, kacang hijau, kedelai, pisang, ketela pohon, tomat, cabai, jahe dan durian. Tanaman-tanaman ini selain dapat kita gunakan sehari-hari atau dapat langsung di makan, juga memiliki manfaat-manfaat yang lain seperti kedelai yang kita tahu bersama merupakan bahan dasar untuk pembuatan tahu dan tempe.Saat ini tanaman kedelai belum banyak di budidayakan di Minahasa Utara untuk itu penulis menyarankan kepada pemrintah Kabupaten Minahasa Utara, kiranya dapat mensosialisasikannya kepada masyarakat.

Untuk desa-desa di sebagian kecamatan Wori yaitu, Darunu, Ponto, Lansa, Bulo, Lantung, Mentehage, Mantehage I, II,III, dan desa Nain memiliki jenis tanah Alluvial Organosol. Jenis tanah ini merupakan gabungan dari jenis tanah alluvial dan jenis tanah organosol. Pada dasarnya jenis tanah alluvial merupakan jenis tanah yang masih muda, belum mengalami perkembangan , berasal dari bahan induk alluvium, tekstur beraneka ragam, belum terbentuk struktur, konsistensi dalam keadaan basah lekat, pH bermacam-macam, kesuburan sedang hingga tinggi. Sedang tanah Organosol merupakan jenis tanah yang berasal dari bahan induk organic seperti hutan rawa atau rumput rawa, dengan ciri dan sifat: tidak terjadi diferensiasi horizon secara jelas, ketebalan lebih dari 0,5 meter, warna coklat hingga kehitaman, tekstur debu lempung, tidak berstruktur, konsistensi tidak lekat-agak lekat, kandungan organic lebih dari 30\% untuk tanah tekstur lempung dan lebih dari $20 \%$ untuk tanak testur pasir, umumnya bersifat sangat asam ( $\mathrm{pH} 4.0$ ), kandungan unsure hara rendah. Untuk jenis tanah alluvial Organosol tanaman yang paling cocok dibudidayakan yaitu tanaman perkebunan yaitu seperti kelapa, kelapa sawit, jati, dan karet. Masing-masing tanaman ini memiliki manfaat seperti tanaman jati, batang pohon jati merupakan bahan kayu yang berkwalitas tinggi dan sangat cocok dibuat sebagai bahan kayu untuk bangunan. Selain itu juga bisaijadikan bahan untuk membuat meubel seperti kursi, meja, lemari dll. Akar pohon jati yang sudah dewasa bisa dijadikan bahan untuk meja. Untuk jenis tanah ini tanaman yang masih jarang dibudidayakan di kabupaten Minahasa Utara adalah tanaman jati, kelapa sawit dan karet. Untuk desa Tarabitan yang memiliki jenis tanah Organosol maka tanaman yang cocok untuk dibudidayakan sama dengan jenis tanah Alluvial Organosol.

Untuk desa Kema 1,2,3, Lansot, Lilang, Kauditan 1,2, Kawiley, warukapas dan Klabat memiliki jenis tanah Regosol. Regosol merupakan jenis tanah yang umumnya belum jelas membentuk diferensiasi horizon, tekstur tanah biasa kasar, struktur kersai atau remah, $\mathrm{pH}$ 6-7. Tanaman yang cocok untuk jenis tanah Regosol yaitu pala, padi sawah, padi gogo, dan jagung.

Untuk jenis tanah regosol tanaman yang masih kurang dibudidayakan adalah tanaman pala. untuk itu penulis menyarankan kepada pemrintah Kabupaten Minahasa Utara, kiranya dapat mensosialisasikannya kepada masyarakat. Untuk desa yang memiliki jenis tanah alluvial regosol seperti Makalisung dan Waleo tanaman yang cocok dibudidayakan adalah sama dengan tanaman untuk jenis tanah Regosol.

Untuk desa-desa seperti Kawangkoan, Kolongan, Suwaan, Matungkas, Kolongan Talawaan, Mapanget, Rap-rap, Saroinsong II dan Sukur memiliki jenis tanah Alluvial Latosol dimana jenis tanah ini memiliki karakteristik : mudah di garap, mengandung cukup hara, subur dan tidak terlalu liat. Dengan karakteristik tanah yang sedemikian desa-desa tersebut diharapkan bisa menghasilkan produksi pertanian yang baik. Tanaman yang paling cocok dibudidayakan pada dasarnya sama dengan tanaman untuk jenis tanah Latosol.

\section{Kemiringan Lereng}

Berikut ini adalah peta berdasarkan kemiringan lereng (lihat Gbr. 5)

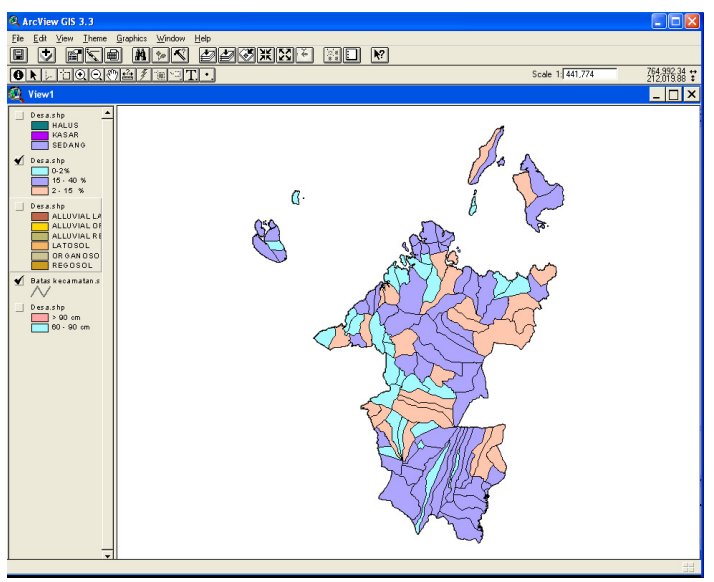

Gbr. 5 Peta berdasarkan Kemiringan Lereng 
Dari peta diatas kita dapat melihat bahwa diwilayah Kabupaten Minahasa Utara terdapat 4 kelas kemiringan lereng, diantaranya:

1) Kemiringan $0-2 \%$ (datar)

Menurut Arsyad (1982) tanah ini tergolong sangat baik dengan permukaan datar danlereng $0-2 \%$. Tanah tidak peka terhadap erosi. Tekstur lempung dan mudah di olah permeabilitas tanah sedang dan drainasse baik sampai sedang. Tanah ini hampir tidak ada pembatas dalam penggunaan.

2) Kemiringan 2 - 15\% (landai dan agak miring) Penggunaan lahan untuk kemiringan seperti ini apabila kita hendak mengunakan untuk tanaman semusim seperti jagung di antara tanaman kelapa maka diperlukan tindakan konservasi tanah seperti pembuatan teras guludan dan pengolahan tanah memotong lereng.

Pengolahan tanah dan penanaman menurut garis kontur dapat mengurangi laju erosi sampai $50 \%$ debandingkan dengan pengolahan tanah dan penanaman menurut lereng. Pada pengolahan tanah menurut lereng, pembajakan atau pencangkulan dilakukan memanjang kearah bawah lereng membentuk alur-alur dan menyebabkan terjadinya konservasi air yang mengalir dengan peta kearah bawah. Sedangkan pada pengolahan tanah menurut kontur, pembajakan dilakukan memotong lereng atau mengikuti kontur sehingga terbentuk jalur-jalur tumpukan tanah dan alur yang sejajar atau mengikuti garis kontur. Pengolahan menurut kontur akan lebih efektif jika diikuti oleh penanaman menurut kontur pula (Suripin 2002). Selanjutnya Suripin (2000) mengatakan bahwa guludan adalah tumpukan tanah yang dibuat memanjang memotong kemiringan lereng. Fungsi guludan adalah untuk menghambat aliran prmukaan, menyimpan air dibagian atasnya dan untuk memotong panjang lereng. Tinggi tumpukan tanah berkisar antara 25-30 cm dengan lebar dasar 25-30 cm. jarak antara guludan bervariasi tergantung pada kecuraman lereng dan kepekatan tanah terhadap erosi. Pada tanah dengan kepekatan erosi rendah guludan dapat di terapkan pad lahan dengan kemiringan lereng sampai $6 \%$. Teras adalah timbunan tanah yang di buat melintang atau memotong kemiringan lereng yang berfungsi untuk menangkap aliran permukaan, serta mengarahkannya ke out let yang mantap dengan tingkat kecepatan yang kurang. Dengan demikian memungkinkan terjadinya penyerapan air dan berkurangnya erosi.

Menurut Arsyad (2000) tanah dengan lereng landai yang terancam erosi sedang jika dipergunakan untuk tanaman semusim memerlukan salah satu atau kombinasi tindakantindakan berikut : guludan, penaanaman dalam stri, pengolajan menurut kontur, pergiliran tanaman dengan rumput leguminosa, mulsa selain dari pemupukan, secara tepatnya tindakan atau kombinasi tindakan yang akan diterapkan, dipengaruhi oleh sifat-sifat tanah, iklim dan sistim usaha tani. Pada lereng agak miring memerlukan drainasse dan pengolahan tanah yang dapat memelihara atau memperbaiki perubahan dan keadaan olah tanah.untuk mencegah pelumpuran dan pemadatan dan memperbaiki permeabilitas umumnya diperlukan pemanbahan bahan organic dan tidak mengolah tanah sewaktu tanah masih basa. Pada lereng agak miring tindakan -tindakan konservasi tanah untuk mencegah erosi sangat diperlukan seperti: guludan bersaluran, penanaman dalam strip, penggunaan mulsa, pergiliran tanaman dan pembuatan teras atau kombinasi dari tindakan-tindakan terse Pengolahan tanah adalah setiap manipulasi mekanik terhadap tanah yang mempunyai tujuan utama yaitu menyiapakan tempat tumbuh bagi benih, menggemburkan tanah pada daerah perakaran, membalikkan tanah sehingga tanaman terbenam dalam tanah dan memberantas gulma (suripin 2002).

3) Kemiringan $15-40 \%$ (miring atau berbukit dan agak curam)

Arsyad (2000) mengatakan bahwa kelas lereng ini pengolahan tanahnya harus hati-hati dan tindakan konservasi lebih sulit diterapkan dan di pelihara seperti teras bangku, saluran bervegetasi dan dam penghambat, di samping tindakan yang dilakukan untuk memelihara kesuburan dan kondisi fisik tanah. Lahan ini dapat digunakan untuk tanaman semusim dan lahan pertanian pada umumnya, tanaman rumput, hutan produksi, padang oengembalaan dan hutan lindung atau suaka alam.Teras bangku atau tangga dibuat dengan jalan memotong lereng dan meratakan tanah di bagian bawah sehingga terbentuk suatu deretan anak tangga atau bangku yang dipisahkan oleh talud. Teras bangku cocok untuk lahan dengan kemiringan 30 derajat atau kurang dari $50 \%$ yang masih difingsikan sebagai lahan pertanian. Talud merupakan bagian yang kritis terhadap bahaya erosi dan biasanya dilindungi dengan tumbuhan rumput atau kadang-kadang dilapisi dengan tumpukan batu kali atau beton untuk lahan yang ditanami komoditas dengan nilai ekonami tinggi. Menurut Kastapoetra (1989) teras bangku berfungsi untuk:

- Mengendalikan erosi dengan mengurangi kemiringan pada tanah atau daerahdaerah yang dijadikan sebagai lahan pertanian.

- Menjadikan tanah yang curum agar memungkinkan digunakan sebagai lahan pertanian.

\section{Tekstur Tanah}


Tekstur tanah adalah perbandingan relative tiga golongan besar partikel tanah dalam suatu massa tanah, terutama perbandingan antara fraksifraksi lempung (clay), debu (silt), dan pasir (sand). Butir tunggal tanah diberi istilah partikel tanah, dan golongan partikel tanah diberi istilah fraksi tanah. (Darmawijaya 1992)

Tesktur tanah suatu horizon tanah merupakan sifat yang hampir tidak berubah, berlainan dengan struktur dan konsistensi. Memang kadng-kadang didapati perubahan dalam lapisan itu sendiri karena dipindahkannya lapisan permukaan atau berkembangnya lapisan permukaan yang baru. Pemindahan ini dapat juga disebabkan oleh erosi tanah. Karena sifatnya yang relative tetap untuk jangka waktu tertentu maka tekstur tanah sudah lama menjadi dasar klasifikasi fisika tanah. Istilah popular tanah berat dan tanah ringan yang merupakan berat ringannya penggarapan tanah seolah-olah ditentukan tekstur tanah, karena para petani sudah lama mengetahui bahwa tanah pasir adalah tanah ringan dan tanah lempung adalah tanah berat.Tekstur tanah turut menentukan tata air dalam tanah, berupa kecepatan infiltrasi, penetrasi dan kemampuan pengikatan air oleh tanah.

Untuk mendapat gambaran yang lebih objektif mengenai tekstru tanah, para pakar tanah mengolongkan besar partikel tanah atas beberapa golongan yang disebut fraksi tanah. Terkenal 2 sistem klasifikasi fraksi partikel tanah ialah:

1) Sistem internasional yang pertama kali diusulkan oleh Atterberg, dan

2) Sistem USDH yang di susun oleh United State Departement of Agriculture yang digunakan di sekuruh dunia.

Dari pengolongan diatas yang terpenting ialah:

1) Fraksi pasir (sand): diameternya antara $2 \mathrm{~mm}$ dan $0,05 \mathrm{~mm}(50 \mu)$

2) Fraksi debu (silt) : diameternya antara $50 \mu$ dan $2 \mu$,

3) Fraksi lempung (clay) : diameternya lebih dari $2 \mu$.

Partikel yang lebih kecil dari $2 \mathrm{~mm}$ disebut pula contoh tanah halus. Yang lebih besar dari $2 \mathrm{~mm}$ tidak dianggap tanah dan digolongkan sebagai krikil untuk yang lebih kecil dan batu untuk yang besar dengan batas kurang lebih $20 \mathrm{~mm}$. Bedasarkan table diatas dapat dilihat bahwa partikel-partikel pasir ukurannya jauh lebih besar dan memiliki luas permukaan yang kecil (dengan berat yang sama) dibandingkan dengan partikelpartikel debu dan liat. Luas permukaan liat sendiri sangat jauh lebih besar dari luas permukaan butiran debu.

Oleh karena luas permukaan pasir adalah kecil, maka perananya dalam ikut mengatur sifatsifat kimia tanah adalah kecil sekali. Disamping itu, disebabkan fraksi pasir itu mempunyai luas permukaan yang kecil tetapi memiliki ukuran yang besar, maka fungsi utamanya adalah sebagai penyokong tanah dalam dimana sekelilingnya terdapat partikel liat dan debu yang lebih aktif. Kecuali terdapat dalam jumlah yang kecil maka jika semakin tinggi prosentase pasir dalam tanah semakin banyak ruang pori-pori diantara partikelpartikel tanah semakin dapat memperlancar gerakan udara dan air.

Pasir dan debu berasal dari pecahnya butirbutir mineral tanah yang ukurannya berbeda dari satu jenis tanah ke jenis tanah yang lain. Luas permukaan debu lebih luas dari permukaan pasir, tingkat pelapukan debu dan pembebasan unsure hara untuk diserap akar lebih besar dari pasir.

Tanah-tanah yang memiliki kemampuan dasar dalam memegang air adalah fraksi liat. Sedangkan tanah-tanah yang mengandung debu yang tiggi dapat memegang air yang tersedia untuk tanaman. Fraksi liat pada kebanyakan tanah terdiri dari mineral-mineral yang berbeda-beda komposisi kimianya dan sifat-sifat lainnya dibandingkan dengan pasir dan debu. Fraksi liat memiliki jumlah luas permukaan yang besar. Di dalam tanah molekul-molekul air mengelilingi partikel-partikel liat berbentuk selapaut tipis sehingga jumlah liat akan menentukan kapasitas memegang air dalam tanah. Selain itu permukaan liat dapat mengabsorbsi sejumlah unsur-unsur hara dalam tanah. DEnagn demikian liat yang permukaan negatif dianggap sebagai penyimpanan air dan makanan untuk tanaman.

Penggolongan tekstur tanah didasarkan atas perbandingan kandungan lempung, debu dan pasir penyusun tanah. Nama klas tekstur tanah pada umumnya di ambil dari fr aksi yang sebagian besar di kandung massa tanah tersebut jika campuran partikel lain dapat diabaikan karena sedikitnya, sehingga di kenal tekstur tanah:

1) Tanah pasir kasar (coarse sand)

2) Tanah pasir (sand)

3) Tanah pasir sangat halus (very fine sand)

4) Tanah debu (silt)

5) Tanah lempung (clay)

6) Tanah lempung berat (heavy clay)

Jika tercampur sedikit fraksi lain maka namanama klas tekstur tanah menjadi:

1) Tanah lempung pasiran (sandy clay)

2) Tanah lempung debuan (silt clay)

Kecuali juga terdapat istilah geluh (loam) untuk menunjukan massa tanah yang terdiri atas ketiga fraksi dalam perbandingansekitar sama besar, dan jika salah satu agak lebih banyak maka dikenal nama-nama tekstur tanah sebagai berikut:

1) Tanah gelu (loam)

2) Tanah pasir geluhan (loamy sandy)

3) Tanah geluh pasiran (sandy loam) 
4) Tanah geluh debuan (silt loam)

5) Tanah geluh lempungan (clay loam)

6) Tanah geluh lempung pasiran (sandy clay loam)

7) Tanah geluh lempung debuan (silty clay loam)

Determinasi tekstur tanah di lapangan dikerjakan dengan cara menggosok-gosokkan tanah diantara ibu jari dan telunjuk atau jarinya. Untuk mempermudah pengamatan contoh tanah biasanya dibasahi sampai kadar airnyamencapai kapasitas lapangan sehingga dapat diamati sifat litany.

Partikel pasir dijari terasa keras dan tajam. Debu kering terasa seperti talk atau bedak, lembab agak licin seperti sabun. Lempung kering menempung, basah melekat di jari dan liat. Penggumpalan tanah sangat mudah pada tanah lempung dan masih mampu pada debu. Lempung dalam profil tanah tampak mengkilat, terutama tanah lempung berat. Berdasarkan gosokan ini kita dapat memperbandingkan banyaknya fraksi pasir, debu dam lempung.

1) Tekstur tanah secara umum dapat digolongkan atas:

2) Tanah bertekstur kasar ialah pasir dan pasir geluhan,

3) Tanah bertekstur agak kasar ialah geluh pasiran dan geluh pasiran halus,

4) Tanah bertekstur sedang ialah geluh pasiran sangat halus, geluh, geluh debuan dan debu,

5) Tanah bertekstur agak halus ialah geluh lempungan, geluh lempungan pasiran dan geluh lempung debuan,

6) Tanah bertekstur halus ialah lempung pasiran, lempung debuan, dan lempung. Prof. C. F. Shaw (1928, dalam Baver, 1958) menyusun definisi-definisi sebagai berikut :

1) Tanah pasir (sand) ialah tanah lepas-lepas dan bebutir tunggal yang mudah di lihat dan dirasakan, jika dipijak kering berderai, basah tergumpal meremah.

2) Tanah geluh pasiran (sandy loam) ialah tanah mengandung cukup pasir melekat karena adanya debu dan lempung, sedang pasirnya dapat di lihat dan dirasakan di pijat, kering membentuk gumpalan yang mudah pecah lagi, basah mengumpal liat.

3) Tanah geluh (loam) ialah tanah yang mengandung sama banyak pasir, debu, dan lempung, sehingga terasa agak licin dan agak liat, dipijat, basah menggumpal sangat liat.

4) Tanah geluh debuan (silt loam) ialah tanah kering menggumpal tetapi mudah pecah, basah terasa empuk dan menempung, mudah saling melekatmembentuk gumpalangumpalan yang keras.
5) Tanah geluh lempungan (clay loam) ialah tanah bertekstur halus yang dapat pecah menjadi gumpalan-gumpalan yang keras jika kering, dalam keadaan basah pijatan membentuk batang-batang tipis yang sukar pecah dan liat.

6) Tanah lempung (clay) ialah tanah bertekstur halus yang biasanya membentuk gumpalangumpalan keras yang kering, jika basah liat dan melekat di jari di pijat membentuk gulungan-gulungan panjang dan fleksibel. Beberapa jenis tanah lempung halus kadar koloidnya sangat tinggi konsistensinya gembur dan kurang liat dalam sembarangan kandungan air.

Berikut ini adalah peta Kabupaten Minahasa Utara berdasarkan tekstur tanah (lihat Gbr. 6).

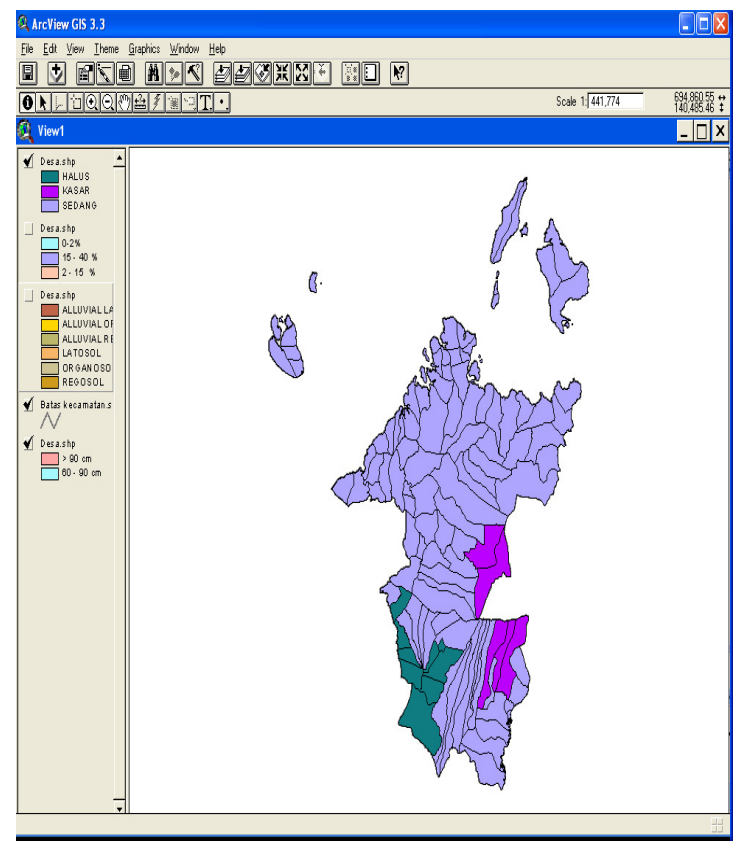

Gbr. 6 Peta berdasarkan Tesktur Tanah

Berdasarkan peta diatas kita dapat melihat bahwa sebagian besar desa-desa di Kabupaten Minahasa Utara memiliki tekstur tanah sedang. Untuk desa-desa seperti Pinilih, Klabat, Kawiley, Kauditan 2 dan Tontalete memiliki tekstur tanah kasar. Untuk desa-desa seperti Airmadidi Atas, Airmadidi bawah, Rap-rap, Sawangan, Tanggari, Sampiri, Kaleosan, Kuwil dan Maumbi memiliki tekstur tanah halus.

\section{Drainase}

Drainase tanah adalah kecepatan perpindahan air dari suatu bidang lahan, baik merupakan run-of Maupin peresapan aiar dalam 
tanah. Drainase sebagai suatu sifat tanah dapat pula diartikan sebagai frekuensi dan lamanya tanah bebas dari kejenuhan air. Evaporasi dan transpirasi menyebabkan hilangnya air ke atas. Drainase tanah selain tampak akibat hasil pengamatan cirri morfologi tanah lain, juga dapat dialami langsung.

Run-of sebagai drainase luar (external) diamati dengan menentukan perbandingan relatif jumlah air yang mengalir dipermukaan tanah dari bidang tanah ke lain tempat terhadap jumlah curah hujan. Dalam hal ini keadaan tanah berdasarkan run-of dapat dibedakan atas :

0-Tergenang : Sama sekali tak ada air keluar sebagai run-of, baik berasal dari hujan maupun dialirkan dari tempat yang lebih tinggi di sekitarnya, sehingga air yang dibuang harus melebihi curah hujan. Hal ini sering terdapat di daerah cekung.

1-Sangat lambat : Aliran air dipermukaan tanah sedemikian lambatnya, sehingga air tergenang dipermukaan tanah untuk waktu lama atau segerameresap ke dalam tanahatau pula diuapkan. Tanah umumnya datar atau hampir datar.

2-Lambat : Aliran air dipermukaan tanah lambtanya, sehingga air masih tergenanguntuk beberapa waktu atau meresap kedalam tanah dan sebagian besar air melalui profil tanah atau mennguap. Permukaan tanahnya hampir datar atau landai, sehingga biasanya kurang begitu berbahaya terhadap erosi.

3-Sedang : Air di permukaan tanah mengalir dengan kecepatan sedemikian rupa, sehingga air dapat meresap ke dalam profil tanah, sedang permukaan tanah masih tetap basah untuk waktu cukup lama. Sebagian besar air hujan diabsorsi tanah dan tersedia untuk digunakan tanaman. Runof tak mengurangi persediaan hara tanaman, sedang bahaya erosi belum begitu membahayakan meskipun untuk bercocok tanam perlu diadakan tindakan pencegahan erosi yang cukup berat.

4-Cepat : Sebagian besr hjan dialirkan segera dengan cepat dipermukaan tanahdan hanya sebagian kecil yang meresap ke dalam profil tanah. Biasanya permukaan tanah merupakan lereng yang miring sampai curam dan mempunyai kapasitas infiltrasi yang rendah, sehingga bahaya erosi cukup besar.

5-Sangat cepat : Hampir semua air yang diturunkan hujan dialirkan dengan cepat di permukaan tanah. Biasanya permukaan tanah merupakan lereng yang curam sampai sangat curam dengan kapasitas infiltrasi yang sangat lambat, sehingga bahaya erosi sangat besar.

Peresapan aiar kedalam tanah sebagai drainasedachil (internal) adalah kualitas tanah yang menurunkan sejumlah air dinyatakan dalam frekuensi dan lamanya penjenuhan air, dan selanjuatnya hal ini dipengaruhi oleh tekstur, struktur dan ciri lainnya. Tinggi air tanah dalam hubungannya dengan air yang ditambahkan pada tanah. Peresapan tanah ini dapat disebabkan oleh: 0-Tanpa peresapan air ke bawah, sehngga terus menerus jenuh air.

1-Sangat lambat : Terlalu lambat untuk pertumbuhan tanaman optimum didaerah basah karena tanah di daerah perakaran tetap jenuh air untuk satu-dua bulan. Kebanyakan mempunyai profil tanah penuh dengan becak-becak (mottlink) dan bintik-bintik, sedang permukaan air tanah biasanya tinggi.

2-Lambat : Masih menghambat pertumbuhan tanaman optimum karena daerah perakaran jenuh untuk satu-dua minggu, profil tanah dengan horizon A atau kelabu, mempunyai becak-becak dan binntik-bintik di bagian bawahnya atau harisan $\mathrm{B}$, sedang permukaan air tanah cukup tinggi.

3-Sedang : Relatif sudah tidak menghambat pertumbuhan tanaman normal karena penjenuhan air di daerah peraksaran sudah terbatas beberapa hari di daerah basah, kebanyakan mempunyai profil dengan horizon A dan hamper semua horizon B yang tak berbecak-becak atau berbintik-bintik.

4-Cepat : Berarti peresapan air terjadi segera tetapi penjenuhan air masih beberapa jam, bahkan terlalu cepat untuk pertumbuhan optimum tanaman-tanaman penting.

5-Sangat cepat : Berati peresapan air melalui prifl tanah sudah terlalu cepat untuk pertumbuhan kebanyakan tanaman, sehingga tanah sampai dalam tertentu tak pernah jenuh air dan sampai dalam sekali tidak berbercak atau berbintik.

Atas dasar pengamatan-pengamatan dan akibat dari pengolongan run-of, peresapan air dan permeabilitas tanah dapat disusun secara klas-klas drainase secara umum yaitu :

0-Sangat buruk : Ada genangan air shingga menghambat pertumbuhan tanaman-tanaman penting kecuali padi, dan sangat memerlukan drainase buatan, sedang tanah pada umumnya menampakan gleisasi.

1-Buruk : Tanah tetap basah untuk waktu lama karena permukaan air tanah dekat atau di permukaan tanah, sehingga menghambat pertumbuhan kebanyakan tanaman perdagangan kecuali dengan drainase buatan.

2-Agak buruk : Air bergerak dari tanah itu cukup lambat untuk dapat membasahi dalam waktu tertentu, biasanya tanah mempunyai lapisan permeabilitasnya rendah atau permukaan air tanah tinggi, dan umumnya masih memerlukan drainase buatan.

3-Sedang : Meskipun air mudah bergerak tetapi masih cukup lambat untuk melembabkan tanah 
guna kepentingan pertumbuhan tanaman normal, umumnya profil tanah lapisan kurang permeable di bagian solum atau permukaan air tanah sedang tingginya

4-Baik : Air segera dapat bergerak tetapi tak cepat, biasanya profil tanah bebas dari becakbecak atau kalau ada di horison $\mathrm{C}$, pertumbuhan tanaman dapat normal.

5-Agak terlalu cepat : Air dikeluarkan dengan cepat, kebanyakan mempunyai diferensisasi horizon yang kecil terdiri atas pasir dan sangat poreus

6-Terlalu cepat : Air dikeluarkan dengan cepat, umumnya merupakan tanag lithosol dan lithosolit, berlereng curam atau sangat curam.

Berikut ini adalah peta berdasarkan drainase kabupaten Minahasa Utara

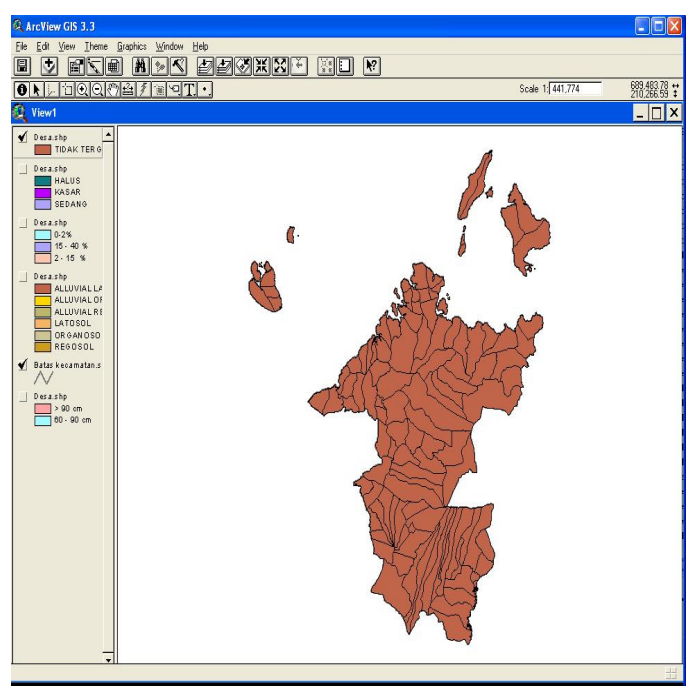

Gbr. 7 Peta Minahasa Utara berdasarkan Drainase

Bedasarkan peta di atas kita dapat melihat bahwa seluruh wilaya kabupaten Minahasa Utara memiliki drainase yang tidak tergenang yang berarti termasuk klas sedang sampai baik. Dimana klas sedang berarti air mudah bergerak tetapi masih cukup lambat untuk melembabkan tanah guna kepentingan pertumbuhan tanaman normal, umumnya profil tanah lapisan kurang permeable di bagian solum atau permukaan air tanah sedang tingginya.

Tujuan utama drainase di lahan pertanian dan kehutanan adalah menurunkan muka air tanah untuk meningkatkan kedalaman dan efektifitas daerah perakaran. Ini berarti bahwa jumlah hara yang mungkin dapat diserap oleh tanaman dapat dipertahankan pada level yang tinggi.

Dengan menghilangnya kelebihan air dalam tanah karena drainase, mengakibatkan turunnya panas jenis tanah sehingga menurunkan jumlah energi untuk menaikkan suhu tanah. Bersamaan dengan itu, evaporasi di permukaan tanah mengalami efek pendinginan. Pada daerah-daerah dimana suhu tanah dan fros menghambat pertumbuhan tanaman, drainase memeungkinkan memperpanjang masa pertanaman. Drainase menurunkan muka tanah memanas lebih cepat, akibatnya perkecambaan lebuh cepat dan pertumbuhan tanaman juga lebih cepat, sehingga secara keseluruhan meningkatkan potensi bagi pertumbuhan tanaman.

Terdapat dua cara yang umum dipakai, yaitu

1) Drainase permukaan seperti tipe drainase saluran. Drainase permukaan adalah cara pengumpulan dan pembuangan air dari permukaan tanah. Tipe drainase ini cocok untuk untuk daerah rendah yang menerima limpahan air dari daerahyang lebih tinggi, dan daerah-daerah yang tanahnya imperiabel sehingga kapasitas melewatkan kelebihan air ke dalam profil tanahnya rendah. Tipe drainase ini banyak dipakai dalam reklamasi daerah rawa di sepanjang jalanjalan raya dan daerah pemukiman di kota. Tipe drainase saluran ini mempunyai keuntungan dapat menampung air banyak dan menyalurkannya secara cepat. Sebaliknya ia memerlukan tempat yang luas, biaya perawatan yang tinggi yaitu setiap kali harus dibersihkan.

2) Drainase dalam seperti tipe drinase gonggorong. Drainase saluran dapat dibuat dengan muda dan murah untuk menyalurkan air gravitasi. Tetapi saluran merupakan pembersih secara periodic menyulitkan penggunaan mesin. Bila secara ekinomis dapat dipertanggungjawabkan drainase gonggorong lebih menguntungkan dan dapat diandalkan. Gonggorong dibuat dari tanah liat yang di bakar berukurab $30 \mathrm{~cm}$ sampai $80 \mathrm{~cm}$ dengan diameter bervariasi dari 0 sampai beberapa pulah sentimeter. Mereka di pasang sambung menyambung denga cela pada sambungan di dalam saluran yang telah disiapkan. Celah pada sambungan dibalut dengan bahan porous untuk menjamin pemasukan air atau agar tidak di sumbat. Gonggorong kemudian di tutup dengan tanah. Sistem pemasangan gonggorong disesuaikan dengan keadaan wilayah. Pada wilayah yang memiliki drainase alamiah, maka gonggorong hanya di pasang di daerah depresi atau cekungan. Ini disebut system drainase alamiah dimana gonggorong membantu hilangnya air dari tempat-tempat akumulasi secara alamiah.

\section{Kesimpulan}

Kesimpulan dari penelitian ini adalah:

1. Dengan bantuan SIG dapat diketahui keadaan tanah seperti jenis tanah, 
kemiringan lereng, tekstur tanah, drainase dan kedalaman efektif.

2. Dengan program ini juga dapat diketahui jenis tanaman yang cocok untuk dibudidayakan oleh petani untuk memperoleh peningkatan produktifitas pertanian berdasarkan jenis tanah

3. Program ini bisa memberikan informasi kepada siapa saja yang ingin mengetahui tentang pengembangan potensi pertanian di kabupaten Minahasa Utara secara cepat dan akurat dengan demikian lebih menghemat waktu, tenaga dan biaya

\section{Referensi}

[1] Abidin, Hassanudin. 2003, Optimalisasi Manfaat Teknologi GPS, [On-line] Available http://www.lib.itenas.ac.id

[2] Budiyanto, Eko. 2002, Sistem Informasi Geografis Menggunakan ArcView GIS, Yogyakarta : ANDI

[3] Budiyanto, Eko. 2004, Sistem informasi geografis menggunakan Map Info,

Yogyakarta : ANDI

[4] Prahasta, Eddy. 2001, Konsep Konsep dasar Sistem Informasi Geografis, Bandung : Informatika

[5] Prahasta, Eddy. 2002, Sistem Informasi Geografis : Tutorial Arview,

Bandung : Informatika

[6] Prahasta, Eddy. 2004, Sistem Informasi Geografis tools and Plug-Ins,

Bandung : Informatika

[7] Prahasta, Eddy. 2004, Sistem Informasi Geografis : Arview Lanjut, Pemrograman Bahasa Script,

Bandung : Informatika

[8] Sutanto. Pengetahuan dasar Interpretasi citra.Laboratorium Penginderaan jauh UGM Yogyakarta

[9] Arsyad, S.2000. Konservasi Tanah dan Air. Institut Pertanian Bogor. Bogor

[10] Darmawijaya, M. I. 1990. Klasifikasi Tanah Dasar Teori Bagian Penelitian Dan Pelaksanaan Pertanian di Indonesia. Fakultas Pertanian Universitas Gajamada 